\title{
Relationship of Gelatinase B Enzyme Activity and Coronary Artery Disease
}

\author{
Ayşegül B ${ }^{1}$, Meral Urhan $\mathrm{K}^{2}$, Gökhan $\mathrm{B}^{3}$ and Çağatay $\mathbf{K M}^{4}$ \\ ${ }^{1}$ Department of Nutrition and Dietetics Artvin, Artvin Coruh University, Turkey \\ ${ }^{2}$ Department of Medical Biology, Mustafa Kemal University, Turkey \\ ${ }^{3}$ Department of Health Sciences, Artvin Coruh University, Turkey \\ ${ }^{4}$ Department of Measurement and Evaluation, Artvin Coruh University, Turkey
}

Submission: November 22, 2017; Published: January 26, 2018

*Corresponding author: Aysegul Bayramoglu, Department of Nutrition and Dietetics, Artvin Coruh University, Turkey, Tel: $+90-466-2151063 / 2103$, Fax: +90-466-215-2151064; Email: atbayramoglu@gmail.com

\begin{abstract}
Matrix metalloproteinases (MMPs) play an important role in the pathogenesis of atherosclerosis, the pathology underlying the majority of coronary artery disease (CAD). We planned to investigate the association of enzyme activities of gelatinase B (or matrix metalloproteinase-9) in CAD patients. For this reason,102 patients with CAD and 99 control group recruited in this study. Serum gelatinase B enzyme level determinated from these peripheral blood samples by using Enzyme-Linked Immunosorbent Assay (ELISA). The results were evaluated by using statistical analyses. The level of gelatinase B increased in patients according to control group. As a result of our study, serum gelatinase B level was associated with CAD and could be used as a clinical marker.
\end{abstract}

Keywords: Coronary Artery Disease; Gelatinase B; MMP-9 Enzyme

Abbreviations: MMPs: Matrix Metalloproteinases; CAD: Coronary Artery Disease; ELISA: Enzyme-Linked Immunosorbent Assay; MMPs: Matrix Metalloproteinases; ECGs: Electrocardiograms; CRP: C Reactive Protein HDL: High-Density Lipoprotein; LDL: Low-Density Lipoprotein; ARTS: Arterial Revascularization Therapies Study; BMI: Body Mass Index; BP: Blood Pressure; DM: Diabetes Mellitus; MI: Myocardial Infarction

\section{Introduction}

Coronary artery disease (CAD) is a complex genetic disease influenced by both genetic and environmen 7 tal factors [1,2]. CAD is one of the most important health problems in the World [3]. Athero $\urcorner$ sclerosis is major cause of CAD characterized by plaque formation, alteration and progression to un $\neg$ stable plaques prone to rupture and complete occlu $\neg$ sion [2]. The matrix metalloproteinases (MMPs), a family of zinc dependent enzymes with proteolytic activity against connective tissue proteins such as collagens, proteoglycans, and elastin [4], appear to play important roles in the development and progression of the atherosclerotic lesion [5]. At the same time, MMPs are thought to participate in the pathogenesis of coronary artery disease [6]. Because in the cardiovascular system has many individual cells that secrete MMPs. Among these are the endothelial cells and vascular smooth muscle cells. Inflammatory cells are the source of MMPs in pathologic processes [7,8].

Gelatinase B (also known as MMP-9 and 92-kDa type IV collagenase), one of the MMP family, is highly expressed in the vulnerable regions of the atherosclerotic plaque. Gelatinase B enzymatically active in atherosclerotic plaques, and are known to be associated with the progression and development of atherosclerotic lesions [9-12]. Studies have reported that gelatinase $\mathrm{B}$ associated with coronary artery disease $[10,13$ 17]. Coronary artery disease, can be prevented or significantly delayed, has been reported to be a disease [18]. Therefore; risk factors of coronary artery disease should be keep under control. In addition, patients with the early diagnosis of coronary artery disease may maintain a healthy life with treatment. For this reason, researchers, as well as the prevention of atherosclerosis, need to work on the new markers for early diagnosis. Our study was planned to explain the relationship between gelatinase B enzyme activity and coronary artery disease and with the aim of examining the role of this enzyme activity in coronary artery disease development.

\section{Materials and Methods}

This study included 102 coronary artery disease patients and 99 controls. Informed consent was obtained from each patient in accordance with a study protocol approved by the ethics committee of Adıyaman University. The patients who applied to the Cardiology Department of Adıyaman 82nd Year State Hospital 
underwent elective coronary angiography for evaluation of cardiac symptoms, abnormalities in electrocardiograms (ECGs), or positive stress tests. Patients with a history of acute coronary syndrome in the last 1 month, chronic cardiac failure, valvular heart disease, congenital heart disease, cardiomyopathy, chronic kidney disease, hepatic dysfunction, respiratory illness, prior stroke, and active infection were excluded from the study. All patients underwent selective coronary angiography under local anesthesia via the femoral artery using the Judkins technique. The definition of the coronary tree segments is based on the classification proposed by the AHA and modified for the Arterial Revascularization Therapies Study (ARTS) I and II. A lesion is defined as significant when it causes a $60 \%$ reduction in luminal diameter by visual assessment.

Fasting blood samples were drawn and the serum were separated and stored at $-80{ }^{\circ} \mathrm{C}$ until analyzed for the serum gelatinase $\mathrm{B}, \mathrm{C}$ reactive protein (CRP) high-density lipoprotein (HDL), low-density lipoprotein (LDL), total cholesterol, and triglyceride. Gelatinase B enzyme activity was measured using
ELISA kit (eBioscience, Vienna, Austria) (22). The serum CRP, HDL, LDL total cholesterol and triglyceride levels were immediately measured with a commercialkit (Roche Diagnostics, Mannheim, Germany) using an auto analyzer (Roche/Hitachi Cobas c Systems, Basel, Switzerland). Statistical analysis was performed running packet program of SPSS (Statistical Package for Social Sciences, SPSS 19.0) software. Parameter values of risk factors were compared with two independent sample $t$ test and Mann Whitney-U test (Table 1). CRP values, which are between patient and control groups, were compared with Mann Whitney U Test. Gelatinase B Enzyme activity, which are between patient and control groups, were also compared with by using two independent sample $t$ test. Comparison of the categorical variables (such as: gender, ...) between groups were performed with Pearson Chi-Square Test, Yates' Chi-Square Test and Fisher's Exact Test. Further, continuous variables were compared between groups with Mann-Whitney U Test for the non-normal variables (Table 2 ). The $\mathrm{p}$ values less than 0.05 were accepted as significant.

Table 1: Comparasion of baseline characteristics of case patients (CAD) and the controls.

\begin{tabular}{|c|c|c|c|}
\hline Risk factors & $\begin{array}{c}\text { Controls }(n=99) \\
\text { Mean } \pm \text { SD }\end{array}$ & $\begin{array}{c}\text { CAD }(n=102) \\
\text { Mean } \pm S D\end{array}$ & P-value \\
\hline Smoking $( \pm) n(\%)$ & $9(9 \%) / 90(91 \%)$ & $24(24 \%) / 78(76 \%)$ & $\mathrm{p}=0.200 \mathrm{a}$ \\
\hline Alchol $( \pm) n(\%)$ & 7 (7.07\%) / $92(92.9 \%)$ & $15(14.7 \%) / 87(85.3 \%)$ & $\mathrm{p}=0.384 \mathrm{~b}$ \\
\hline $\mathrm{DM}( \pm) \mathrm{n}(\%)$ & 7 (7.07\%)/ 92 (92.9\%) & $27(26.5 \%) / 75$ (73.5\%) & $\mathrm{p}=0.010 \mathrm{a}$ \\
\hline MI $( \pm) n(\%)$ & $0(0.0 \%) / 99(100 \%)$ & $64(62.74 \%) / 38(37.25 \%)$ & $\mathrm{p}<0.001 \mathrm{a}$ \\
\hline Stroke $( \pm)$ n $(\%)$ & $0(0.0 \%) / 99(100 \%)$ & $17(16.66 \%) / 85(83.33 \%)$ & $\mathrm{p}=0.429 \mathrm{~b}$ \\
\hline BMI (kg/m2) & $26.91 \pm 3.85$ & $27.2 \pm 3.74$ & $\mathrm{p}=0.849^{*}$ \\
\hline Sistolic BP (mmHg) & $124.61 \pm 11.99$ & $123.9 \pm 21.08$ & $\mathrm{p}=0.347^{*}$ \\
\hline Diastolic BP (mmHg) & $78.29 \pm 10.06$ & $76.35 \pm 12.19$ & $\mathrm{p}=0.142^{*}$ \\
\hline Total cholesterol, mg/dL & $194.39 \pm 34.94$ & $186.35 \pm 50.48$ & $\mathrm{p}=0.018^{*}$ \\
\hline HDL cholesterol, mg/dL & $46.06 \pm 13.96$ & $39.81 \pm 9.75$ & $\mathrm{p}=0.003^{*}$ \\
\hline LDL cholesterol; mg/dL & $113.55 \pm 32.95$ & $111.13 \pm 44.2$ & $\mathrm{p}=0.188^{*}$ \\
\hline Triglyceride, mg/dL & $175.97 \pm 114.14$ & $179 \pm 130.33$ & $\mathrm{p}=0.736^{*}$ \\
\hline Gender (female/male) & $36(48.0 \%) / 63(49.6 \%)$ & $39(52.0 \%) / 63(50.4 \%)$ & $\mathrm{p}=0.827^{* *}$ \\
\hline
\end{tabular}

*: Mann-Whitney U Test, **: Pearson Chi-Square Test, a: Yates' Chi-Square Test, b: Fisher's Exact Test.

Table 2: Gelatinase B and CRP enzyme levels in control and patients.

\begin{tabular}{|c|c|c|c|}
\hline Parameters & $\begin{array}{c}\text { Control } \\
\mathbf{n = 9 9}\end{array}$ & $\begin{array}{c}\text { CAD } \\
\mathbf{n = 1 0 2}\end{array}$ & Statistic \\
\hline CRP (mg/L) & $7.391 \pm 2,268$ & $21.876 \pm 4.508$ & $\mathrm{p}<0.001^{*}$ \\
\hline $\begin{array}{c}\text { Gelatinase B } \\
\text { (ng/ml) }\end{array}$ & $0.390 \pm 0.027$ & $0.505 \pm 0.025$ & $\mathrm{P}<0.003^{* *}$ \\
\hline
\end{tabular}

*:Mann Whitney U Test, **: T Test.

\section{Results}

The study population included 102 coronary artery disease patients and 99 healty subjects in control group. The main characteristics of the case patients and controls are listed in Table 1. DM history, MI history, total cholesterol, HDL, among risk factors for cardiovascular disease were found different in the patients and the control group $(p<0.05)$. However, there were no differences in gender, stroke history, BMI, and other cardiovascular risk factors as LDL, triglyceride, sistolik and diastolik blood pressure between groups $(p>0.05)$ (Table 1$)$ as statistically. CRP and gelatinase B enzyme levels of controls and all patients were shown in Table 2. Serum gelatinase B enzyme levels in control group and CAD patients were determined as $0.390 \pm 0.027 \mathrm{ng} / \mathrm{ml}$ and $0.505 \pm 0.025$, respectively. Serum CRP levels in control group and CAD patients were determined as $7.391 \pm 2,268 \mathrm{mg} / \mathrm{L}$ and $21.876 \pm 4.508 \mathrm{mg} / \mathrm{L}$ respectively.

\section{Discussion}

In our study, we investigated the relationship between serum gelatinase B enzyme activity and coronary artery disease. The results of the present study indicated that level of serum gelatinase B enzyme was higher than patient group according 
to control group. In accordance with our results, Brunner and his colleagues also have reported that the serum gelatinase B enzyme activity is high in the patient group than in the control [14]. Again, Spurthi and colleagues also found a high level of serum gelatinase B in patients with coronary artery. They have reported that their findings not only are relevant to the understanding of the pathogenesis of atherosclerosis but also may provide a novel target for future development of predictive, preventive, and therapeutic measures [15]. Kalale et al. [16] said that there are findings to indicate that arterial inflammation is reflected in increased serum concentration of gelatinase $B$ and since gelatinase B has been suggested to reflect inflammation in atherosclerotic plaques, it may be useful in the evaluation of the severity of cardiovascular disease. Ferroni et al. [17] also have reported that measurement of serum gelatinase B levels may represent a novel marker of inflammation in patients with known coronary artery disease and might provide an index of plaque activity in this clinical setting. Wang et al. [13] have reported that serum gelatinase B level may be a significant biomarker [13]. Recent studies, researchers have reported that gelatinase B could be a novel biomarker for CAD [10,12]. Also İn our previous study, serum gelatinase B enzyme levels were higher in patients compared to controls [19].

İn one study was found high gelatinase B levels in patients with acute coronary syndromes compared to the control group. At the same time, it has been found a strong correlation between gelatinase B and hs-CRP in acute coronary syndrome group [20]. Inflammation plays an important role in the initiation and progression of atherosclerosis and in the pathogenesis of acute cardiovascular events. CRP is one of the major acute phase protein in humans [21,22]. Recent studies have indicated a possible association between CRP and CAD [23]. In studies, in accordance with our findings, CRP level were found higher in patients compared to controls [21,23-25]. Understanding of the contribution of gelatinase B enzyme in atherosclerotic process, will contribute to the development of new diagnostic and therapeutic approaches for CAD. As a result of our study, we can say that gelatinase B levels are associated with CAD and could be used as a clinical marker.

\section{Acknowledgment}

This work was supported by providing samples and diagnosing coronary artery disease patients from Dr. Okay ABACI. We thank Dr. Okay ABACI

\section{References}

1. Morgan AR, Zhang B, Tapper W, Collins A, Ye S (2003) Haplotypic analysis of the MMP-9 gene in relation to coronary artery disease. J Mol Med 81(5): 321-326.

2. Urhan KM, Bayramoglu A, Uzun GS, Kucukkaya Y, Abaci O, et al. (2016) MTHFR and MMP-9 Genetic Variants in Coronary Artery Disease. Dicle Medical Journal 43(1): 50-56.

3. Yusuf S (1998) The global problem of cardiovascular disease. Int J Clin Pract Suppl 94: 3-6.
4. Bayramoglu A, Gunes Hv, Metintas M, Değirmenci I, Mutlu F, et al. (2009) The association of MMP-9 enzyme activity, MMP-9 C1562T polymorphism, and MMP-2 and -9 and TIMP-1, $-2,-3$, and -4 gene expression in lung cancer. Genet Test Mol Biomarkers 13: 671-678.

5. Zhang B, Ye S, Herrmann Sm, Eriksson P, De Maat M, et al. (1999) Functional Polymorphism in the Regulatory Region of Gelatinase B Gene in Relation to Severity of Coronary Atherosclerosis. Circulation 99(14): 1788-1794.

6. Nanni S, Melandri G, Hanemaaijer R, Cervi V, Tomasi L, et al. (2007) Matrix metalloproteinases in premature coronary atherosclerosis: influence of inhibitors, inflammation, and genetic polymorphisms. Translational research 149(3): 137-144.

7. Edep Me, Shirani J, Wolf P, Brown Dl (2000) Matrix metalloproteinase expression in nonrheumatic aortic stenosis. Cardiovasc Pathol 9(5): 281-286.

8. Jian B, Jones Pl, Li Q Mohler ER, Schoen FJ, et al. (2001) Matrix metalloproteinase- 2 is associated with tenascin- $\mathrm{C}$ in calcific aortic stenosis. Am J Pathol 159(1): 321-327.

9. Pöllänen PJ, Karhunen PJ, Mikkelsson J, Laippala P, Perola M, et al. (2001) Coronary Artery Complicated Lesion Area Is Related to Functional Polymorphism of Matrix Metalloproteinase 9 Gene An Autopsy Study. Arterioscler Thromb Vasc Biol 21(9): 1446-1450.

10. Li H, Yuan Z, Li S, Qi Q, Liu J, et al. (2017) Plasma levels of matrix metalloproteinase 9 in patients undergoing off-pump coronary artery bypass grafting. J Thorac Dis 9(4):1100-1106.

11. Beton O, Arslan S, Acar B, Ozbilum N, Berkan O (2016) Association between MMP-3 and MMP-9 polymorphisms and coronary artery disease. Biomed Rep 5(6):709-714.

12. Mirhafez SR, Avan A, Tajfard M, Mohammadi S, Moohebati M, et al. (2017) Relationship between serum cytokines receptors and matrix metalloproteinase 9 levels and coronary artery disease. J Clin Lab Anal 31(5).

13. Wang LX, Lü SZ, Zhang WJ, Song XT, Chen H, et al. (2011) Comparision of high sensitivity C-reactive protein and matrix metalloproteinase 9 in patients with unstable angina between with and without significant coronary artery plaques. Chin Med J 124(11): 1657-1661.

14. Brunner S, Kim JO, Methe H (2010) Relation of matrix metalloproteinase-9/tissue inhibitor of metalloproteinase-1 ratio in peripheral circulating CD14+ monocytes to progression of coronary artery disease. Am J Cardiol 105(4): 429-434.

15. Spurthi KM, Galimudi RK, Srilatha G, Sahu SK, Nallari P, et al. (2012) Influence of gelatinase B polymorphic variants and its serum levels in atherosclerosis. Genet Test Mol Biomarkers 16(8): 850-854.

16. Kalela A, Koivu TA, Sisto T, Kanervisto J, Höyhtyä M, et al. (2002) Serum matrix metalloproteinase- 9 concentration in angiographically assessed coronary artery disease. Scand J Clin Lab Invest 62(5): 337342.

17. Ferroni P, Basili S, Martini F, Cardarello CM, Ceci F, et al. (2003) Serum metalloproteinase 9 levels in patients with coronary artery disease: a novel marker of inflammation. J Investig Med 51(5): 295-300.

18. Elliot WJ (1994) Cardiovascular risk factors. Which ones can and should be remedied? Postgrad med 96(3): 49-58.

19. Bayramoglu A, Kucuk UM, Ercan S, Abaci O, Guler Hi, et al. (2012) Hypertension and matrix metalloproteinase- 9 enzyme activity. Journal of Selçuk University Natural and Applied Science 3: 60-68.

20. Zeng B, Prasan A, Fung KC, Solanki V, Bruce D, Freedman SB, Brieger D (2005) Elevated circulating levels of matrix metalloproteinase- 9 and -2 in patients with symptomatic coronary artery disease. Intern Med J 35(6):331-335. 
21. Uydu HA, Bostan M, Yilmaz A, Demir A, Atak M, et al. (2013) Comparision of inflammatory biomarkers for detection of coronary stenosis in patients with stable coronary artery disease. Eur Rev Med Pharmacol Sci 17(1):112-8.

22. Acarturk E (2004) C-Reactive Protein and Coronary Artery Disease Anadolu Cardiol Derg 4: 203-204.

23. Altek E, Onvural B (2004) Usefulness Of C-Reactive Protein In Cardiovascular Disease As A Risk Factor. T Klin J Med Sci 24: 57-61.
24. Harada K, Amano T, Uetani T, Yoshida T, Kato B, et al. (2013) Association of inflammatory markers with the morphology and extent of coronary plaque as evaluated by 64-slice multidetector computed tomography in patients with stable coronary artery disease. Int J Cardiovasc Imaging 29(5): 1149-1158.

25. Silva D, Pais De Lacerda A (2012) High-sensitivity C-reactive protein as a biomarker of risk in coronary artery disease. Rev Port Cardiol 31(11): 733-745

\section{Your next submission with Juniper Publishers} will reach you the below assets

- Quality Editorial service

- Swift Peer Review

- Reprints availability

- E-prints Service

- Manuscript Podcast for convenient understanding

- Global attainment for your research

- Manuscript accessibility in different formats

( Pdf, E-pub, Full Text, Audio)

- Unceasing customer service

Track the below URL for one-step submission https://juniperpublishers.com/online-submission.php 